\title{
Deformation Behavior and Precipitation Features in a Stretched Al-Cu Alloy at Intermediate Temperatures
}

\author{
Y.C. Lin ${ }^{1,2, *} \mathbb{C}$, Wen-Yong Dong ${ }^{1}$, Xu-Hao Zhu ${ }^{1}$, Qiao $\mathrm{Wu}^{1}$ and Ying-Jie $\mathrm{He}^{1}$ \\ 1 School of Mechanical and Electrical Engineering, Central South University, Changsha 410083, China; \\ mschen77@163.com (W.-Y.D.); ychuang63@163.com (X.-H.Z.); Xianyangwu88@163.com (Q.W.); \\ lingli855@163.com (Y.-J.H.) \\ 2 State Key Laboratory of High Performance Complex Manufacturing, BP156, Changsha 410083, China \\ * Correspondence: yclin@csu.edu.cn; Tel.: +86-013469071208
}

Received: 2 May 2020; Accepted: 27 May 2020; Published: 29 May 2020

\begin{abstract}
Deformation behavior and precipitation features of an $\mathrm{Al}-\mathrm{Cu}$ alloy are investigated using uniaxial tensile tests at intermediate temperatures. It is found that the true stress drops with the decreased strain rate or the increased deformation temperature. The number of substructures and the degree of grain elongation decrease with the raised temperature or the decreased strain rate. At high temperatures or low strain rates, some dynamic recrystallized grains can be found. The type of precipitates is influenced by the heating process before hot tensile deformation. The content and size of precipitates increase during tensile deformation at intermediate temperatures. As the temperature increases over $200{ }^{\circ} \mathrm{C}$, the precipitation process (Guinier Preston zone (G.P. zones) $\rightarrow \theta^{\prime \prime}$ phase $\rightarrow \theta^{\prime}$ phase) is enhanced, resulting in increased contents of $\theta^{\prime \prime}$ and $\theta^{\prime}$ phases. However, $\theta^{\prime \prime}$ and $\theta^{\prime}$ phases prefer to precipitate along the $\{020\}_{\mathrm{Al}}$ direction, resulting in an uneven distribution of phases. Considering the flow softening degree and the excessive heterogeneous precipitation of $\theta^{\prime \prime}$ and $\theta^{\prime}$ phases during hot deformation, the reasonable strain rate and temperature are about $0.0003 \mathrm{~s}^{-1}$ and $150{ }^{\circ} \mathrm{C}$, respectively.
\end{abstract}

Keywords: Al alloy; deformation behavior; precipitation features; phases

\section{Introduction}

In view of their excellent properties, 2xxx series $\mathrm{Al}(\mathrm{Al}-\mathrm{Cu})$ alloys are widely used for aerospace components [1-5]. For instance, rocket engine fuel tanks are usually manufactured using $2 x x x$ $\mathrm{Al}$ alloys [6]. Generally, the tanks are of large diameter and small thickness, and they are often formed by tensile deformation at room temperature. However, during tensile deformation, the work hardening is usually very obvious, and uneven microstructures are induced. Therefore, it is essential to find reasonable deformation parameters (deformation temperature and strain rate) to relieve work hardening and optimize microstructures.

In recent years, many researches on the deformation behavior [7-11] and precipitation features [12-15] of Al-Cu alloys were carried out. Liu et al. [16] described the continuous dynamic recrystallization behavior of a compressed $\mathrm{Al}-\mathrm{Cu}$ alloy at the temperature range of $350-500{ }^{\circ} \mathrm{C}$. Chen et al. [17] researched the high-temperature compressive features of an Al-Cu alloy. Liu et al. [18] found that the main softening mechanism of a compressed 2219 aluminum alloy is dynamic recovery at the temperature range of $250-500{ }^{\circ} \mathrm{C}$. Wei et al. [19] analyzed the morphological changes of S-phase in a high-temperature crept 2024 aluminum alloy under tensile stress. Lin et al. [6] discussed the effects of cooling rate and solution time on the precipitated transformation of an $\mathrm{Al}-\mathrm{Cu}$ alloy, and they found that the precipitation of $\theta^{\prime}$ and $\theta^{\prime \prime}$ phases is enhanced with increased cooling rate and solution time. García-Hernández et al. [20] discovered that fine homogeneous precipitates in a $2024 \mathrm{Al}$ alloy with a 
thickness of $8 \mathrm{~mm}$ can be acquired when the thickness reduction is 15\%. Song et al. [21] found that the dimensional stability of an Al-Cu-Mg alloy can be improved by stress-aging. Paoletti et al. [22] and $\mathrm{Li}$ et al. [23] modeled the creep behavior of an aged $\mathrm{Al}-\mathrm{Cu}-\mathrm{Mg}$ alloy. $\mathrm{Li}$ et al. [24] discussed the synergy influence of pre-straining and $\mathrm{Si}$ addition on microstructures of $\mathrm{Al}-\mathrm{Cu}-\mathrm{Mg}$ alloys. Mirzadeh [25] studied the complex hot deformation mechanisms of 7075 and $2024 \mathrm{Al}$ alloys, as well as developed accurate physically based constitutive models to depict their flow behavior.

The above researches mostly concentrated on the deformation behavior and precipitation features in hot compressed $\mathrm{Al}-\mathrm{Cu}$ alloys, where the deformation temperature is generally higher than $250{ }^{\circ} \mathrm{C}$. However, few investigations focused on the tensile deformation at intermediate temperatures such as below $250^{\circ} \mathrm{C}$. Nevertheless, the researches on the deformation behavior and precipitation features in $\mathrm{Al}-\mathrm{Cu}$ alloys such as 2219 aluminum alloy at intermediate temperatures are significant for the industrial production of large-scale thin-walled ellipsoidal heads. In this work, the deformation behavior of an Al-Cu alloy is investigated by uniaxial tensile tests at intermediate temperatures $\left(100-250{ }^{\circ} \mathrm{C}\right)$. The changes in substructures and grains were analyzed by electron backscattered diffraction (EBSD) analysis. Furthermore, the precipitation features during tensile deformation were investigated by differential scanning calorimetry (DSC), transmission electron microscopy (TEM), and scanning electron microscopy (SEM).

\section{Materials and Experimental Procedures}

The initial experimental material was one typical Al-Cu alloy (2219 aluminum alloy) rolled sheet with $12 \mathrm{~mm}$ thickness. Its chemical composition was $6.37 \mathrm{Cu}-0.30 \mathrm{Mn}-0.16 \mathrm{Fe}-0.12 \mathrm{Zr}-0.05 \mathrm{Si}-0.04$ $\mathrm{Ti}-\mathrm{Al}$ (balance) (wt. \%). The sheet was solution-treated at $535^{\circ} \mathrm{C}$ for $40 \mathrm{~min}$ [6]. Figure 1 displays the cylindrical specimens cut from the sheet along the rolling direction. The tensile deformation experiments were executed on an MTS-GWT2105 test machine (MTS company; Shanghai, China). The experimental temperatures were $100,150,200$, and $250^{\circ} \mathrm{C}$. The strain rates were $0.00003,0.0003$, and $0.003 \mathrm{~s}^{-1}$. The samples were firstly heated to experimental temperatures by $10^{\circ} \mathrm{C} / \mathrm{min}$ and then held for $5 \mathrm{~min}$ to acquire an even temperature field. Afterward, the samples were stretched to $15 \%$ true strain at different strain rates. Finally, the samples were cooled in air to room temperature.

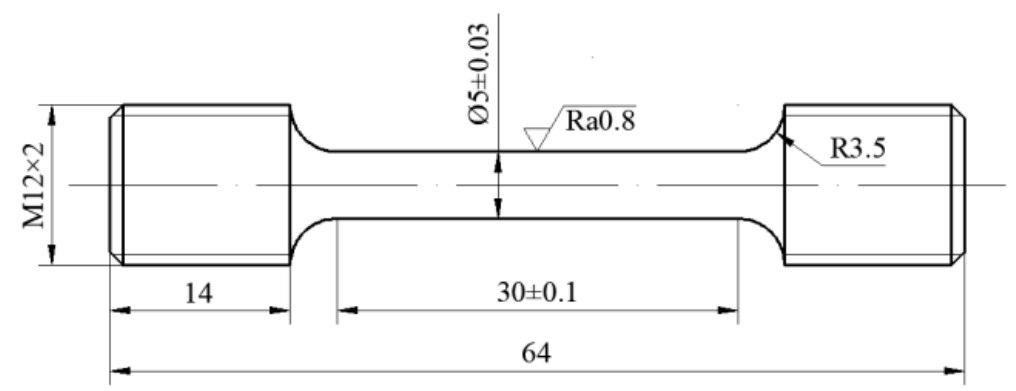

Figure 1. Specific dimensions of cylindrical tensile specimens (unit: $\mathrm{mm}$ ).

To analyze the effects of deformation parameters on microstructures, foils were cut from the central part of stretched samples. The foils were polished by abrasive paper and then thinned by electro-polishing in a solution of $\mathrm{HNO}_{3}(240 \mathrm{~mL})$ and $\mathrm{CH}_{3} \mathrm{OH}(560 \mathrm{~mL})$ at $-30{ }^{\circ} \mathrm{C}$. The prepared foils were analyzed by EBSD (Helios Nanolab 600i; FEI company; Hillsboro, OR, USA) and TEM (Tecnai G2 F20; FEI company; Hillsboro, OR, USA) detectors. Additionally, the content and type of precipitated phases were analyzed by DSC (DSC8500; PerkinElmer company; Waltham, MA, USA). Firstly, to acquire the baseline of DSC, an empty crucible was heated with the heating rate of $10^{\circ} \mathrm{C} / \mathrm{min}$. Then, the samples were grinded with sandpaper and cleaned by anhydrous ethanol. The size of DSC samples was $5 \mathrm{~mm} \times 5 \mathrm{~mm} \times 2 \mathrm{~mm}$, and the mass was between 90 and $110 \mathrm{mg}$. Next, the samples were put in a crucible, and these samples were subsequently heated with the same heating rate. To evaluate the mechanical properties of the alloy, the uniaxial tensile tests were executed on the MTS-GWT2105 test 
machine in the tested condition. After tensile deformation, the fracture morphologies were observed using a JEOL-7001F1 field emission (FE) SEM (FEI Electron Optics B.V; Prague, Czech Republic).

\section{Experimental Findings and Discussions}

\subsection{Deformation Behavior and Mechanisms}

The flow stress curves of the stretched alloy are displayed in Figure 2. The stretched process can be divided into the elastic and plastic deformation stages. In the elastic deformation stage, the true stress linearly rises with the true strain. This is because dislocations quickly accumulate in material. Meanwhile, the rearrangement and annihilation of dislocations are low because of the short deformation time [26,27]. However, in the plastic deformation stage, the slope of the flow stress curve gradually decreases with increased strain. The reason is that the work hardening $(\mathrm{WH})$ gradually weakens, while the dynamic softening is gradually enhanced $[28,29]$. In Figure $2 a, b$, the true stress gradually rises with the increased true strain at $100^{\circ} \mathrm{C}$ and $150^{\circ} \mathrm{C}$. This is because $\mathrm{WH}$ is dominant, but the role of dynamic softening is relatively low at low temperatures [30,31]. In Figure 2c, as the temperature is raised to $200{ }^{\circ} \mathrm{C}$, the true stress still rises with the raised true strain at $0.003 \mathrm{~s}^{-1}$ and $0.0003 \mathrm{~s}^{-1}$. However, it firstly increases and then keeps stable, finally rapidly dropping with the increase in strain at $0.00003 \mathrm{~s}^{-1}$, i.e., the dynamic softening is enhanced. In Figure $2 \mathrm{~d}$, as the temperature is further increased to $250{ }^{\circ} \mathrm{C}$, the true stress increases with the increase in strain at $0.003 \mathrm{~s}^{-1}$. The true stress firstly rises and then keeps stable at $0.0003 \mathrm{~s}^{-1}$. However, obvious dynamic softening behavior is observed at $0.00003 \mathrm{~s}^{-1}$. In general, the true stress is affected by strain rate and temperature. The true stress declines with the increased temperature. The reason is that the thermal motion of atoms is enhanced, which decreases the bonding force of atoms, and plastic deformation easily occurs [25,32,33]. Thus, the role of dynamic softening is more obvious at higher temperatures. In addition, the true stress drops with the decreased strain rate, because the deformation time is enough at low strain rates, enhancing the annihilation and rearrangement of dislocations [34,35]. Then, the true stress drops with decreasing strain rate.
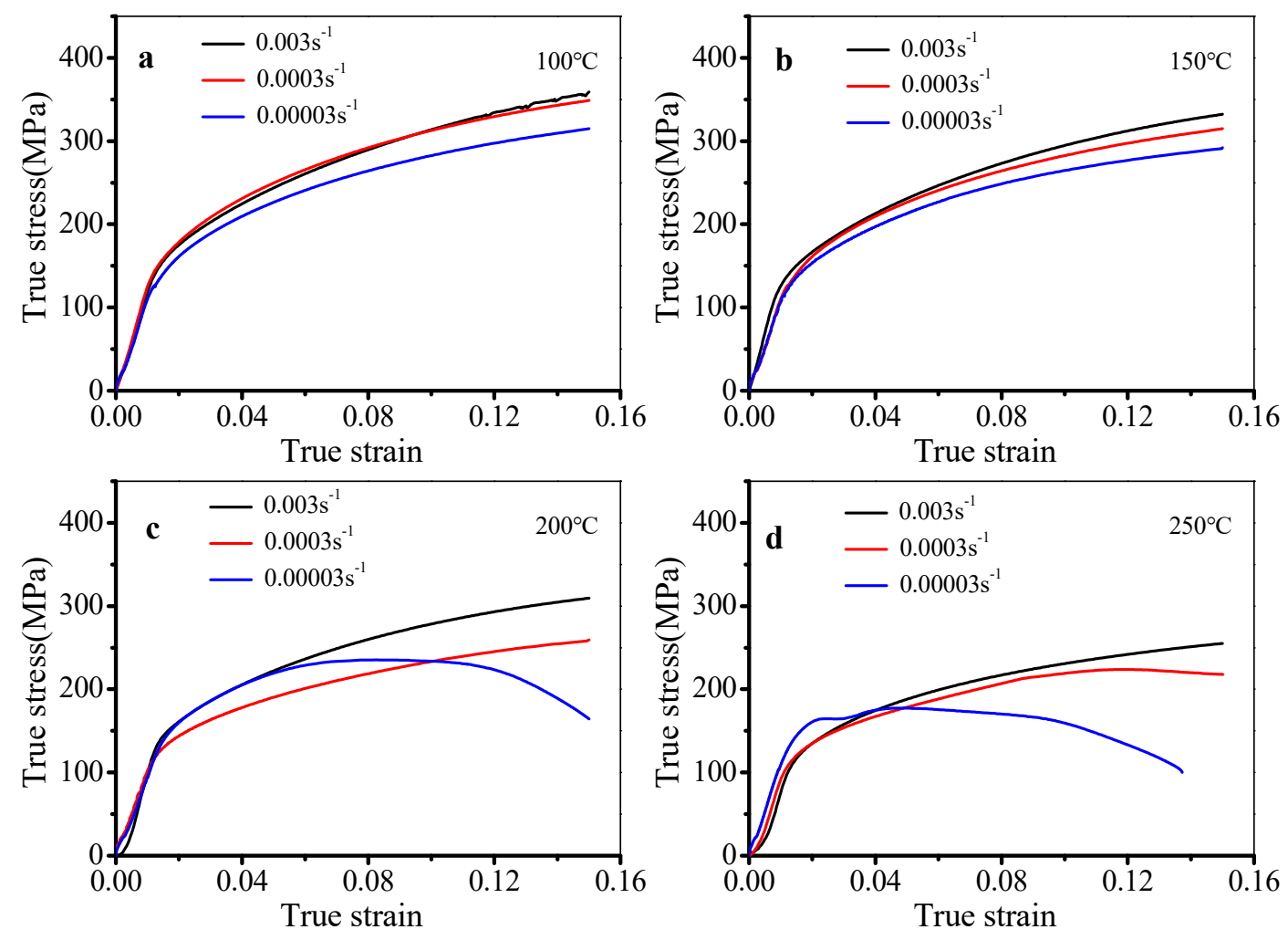

Figure 2. Flow stress curves at (a) $100{ }^{\circ} \mathrm{C}$, (b) $150{ }^{\circ} \mathrm{C}$, (c) $200{ }^{\circ} \mathrm{C}$, and (d) $250{ }^{\circ} \mathrm{C}$. 
Usually, the work hardening rate is used to depict work hardening behavior in deformed alloys. The plots of work hardening rate and true strain in diverse deformation conditions were acquired by differentiating the flow stress curves, as presented in Figure 3. In the elastic deformation stage, the work hardening rate quickly rises. Then, the work hardening rate drops with increasing strain in the plastic deformation stage. In Figure $3 a-d$, it can be noted that the maximum work hardening rate is smaller at lower strain rates or higher temperatures. Meanwhile, the work hardening rate quickly drops in the plastic deformation stage. In most deformation conditions (Figure 3a-c), the work hardening rate does not decrease to zero with the raised strain, except at $200{ }^{\circ} \mathrm{C}$ and $0.00003 \mathrm{~s}^{-1}$. In Figure $3 \mathrm{~d}$, the temperature is raised to $250{ }^{\circ} \mathrm{C}$, while the work hardening rate decreases to zero at $0.0003 \mathrm{~s}^{-1}$ and $0.00003 \mathrm{~s}^{-1}$ when the true strains are 0.115 and 0.048 , respectively. This reveals that the influence of dynamic softening is strong at lower strain rates or higher temperatures.
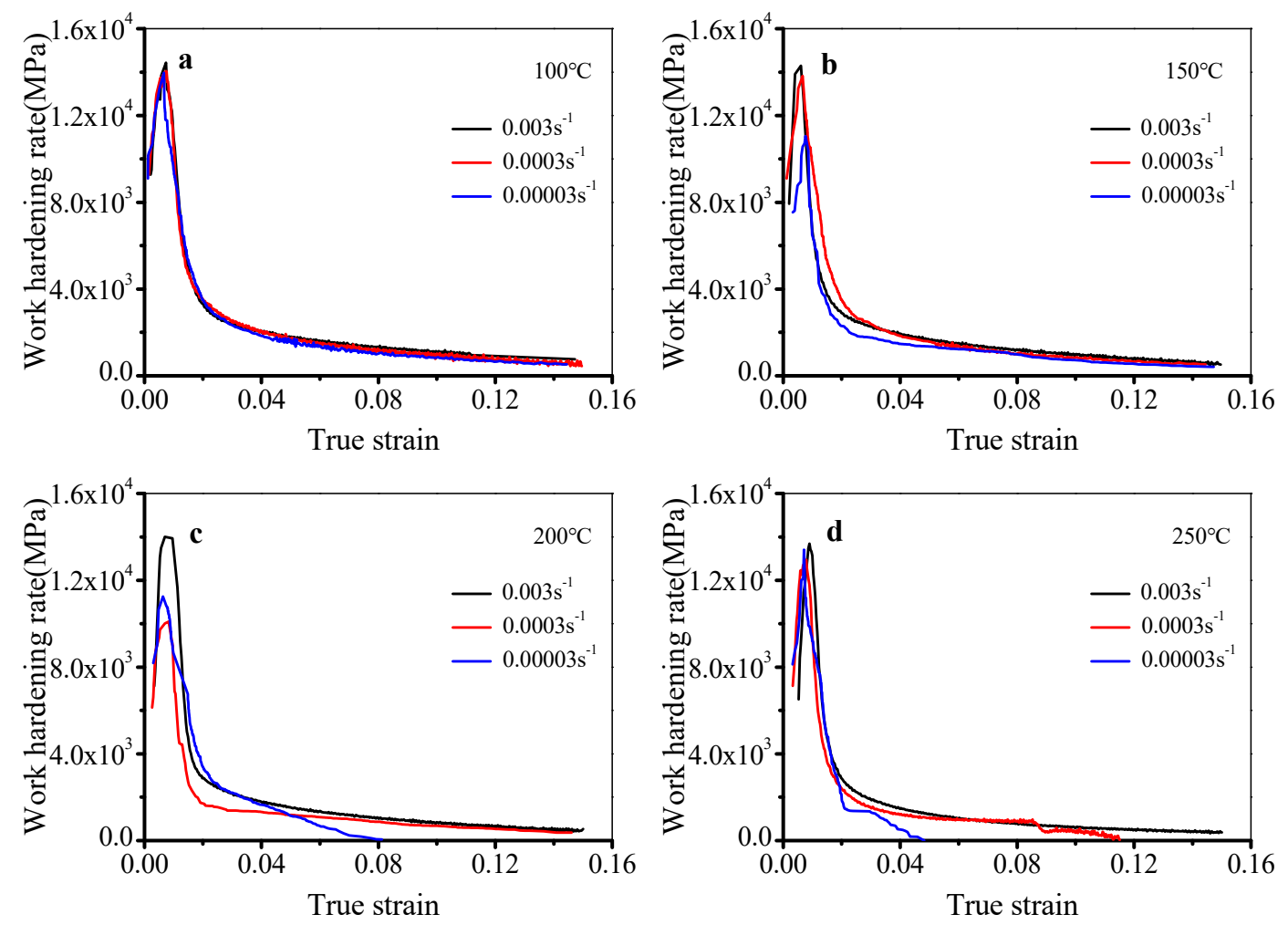

Figure 3. Work hardening rate-true strain curves at (a) $100^{\circ} \mathrm{C},(\mathbf{b}) 150^{\circ} \mathrm{C}$, (c) $200^{\circ} \mathrm{C}$, and (d) $250{ }^{\circ} \mathrm{C}$.

\subsection{Effects of Deformation Parameters on Substructures and Grains}

The inverse pole figure (IPF) maps of the stretched alloy at tested conditions are displayed in Figure 4 . The grains are elongated along the tensile direction (TD) at different temperatures, as depicted in Figure $4 a-d$. The degree of grain elongation decreases with the raised temperature, i.e., the maximum grain elongation changes from $432 \mu \mathrm{m}$ to $321 \mu \mathrm{m}$ while the temperature is raised from $100{ }^{\circ} \mathrm{C}$ to $250{ }^{\circ} \mathrm{C}$. Furthermore, substructures can be observed in Figure 4. The grain boundaries of substructures are low-angle grain boundaries (LAGBs). Here, the misorientation angles with $0^{\circ}<\theta<15^{\circ}$ and $\theta>15^{\circ}$ are referred to as LAGBs and high-angle grain boundaries (HAGBs), respectively. Meanwhile, the number of substructures decreases with the raised temperature. In addition, small fine grains around the elongated original coarse grains can be observed at $250{ }^{\circ} \mathrm{C}$, which are marked with the white dotted line region in Figure $4 \mathrm{~d}$. The grain boundaries of these grains are HAGBs. Generally, LAGBs are formed by dynamic recovery (DRV), while HAGBs are formed by dynamic recrystallization (DRX) [36,37]. DRX grains are formed due to the rotation of small substructures $[38,39]$. This is consistent with those findings of other scholars [40,41]. In Figure $4 \mathrm{e}-\mathrm{f}$, the degree of grain elongation and the number of 
substructures decrease while the strain rate decreases from $0.003 \mathrm{~s}^{-1}$ to $0.00003 \mathrm{~s}^{-1}$. Additionally, some DRX grains can be found at $0.00003 \mathrm{~s}^{-1}$ in Figure $4 \mathrm{f}$.
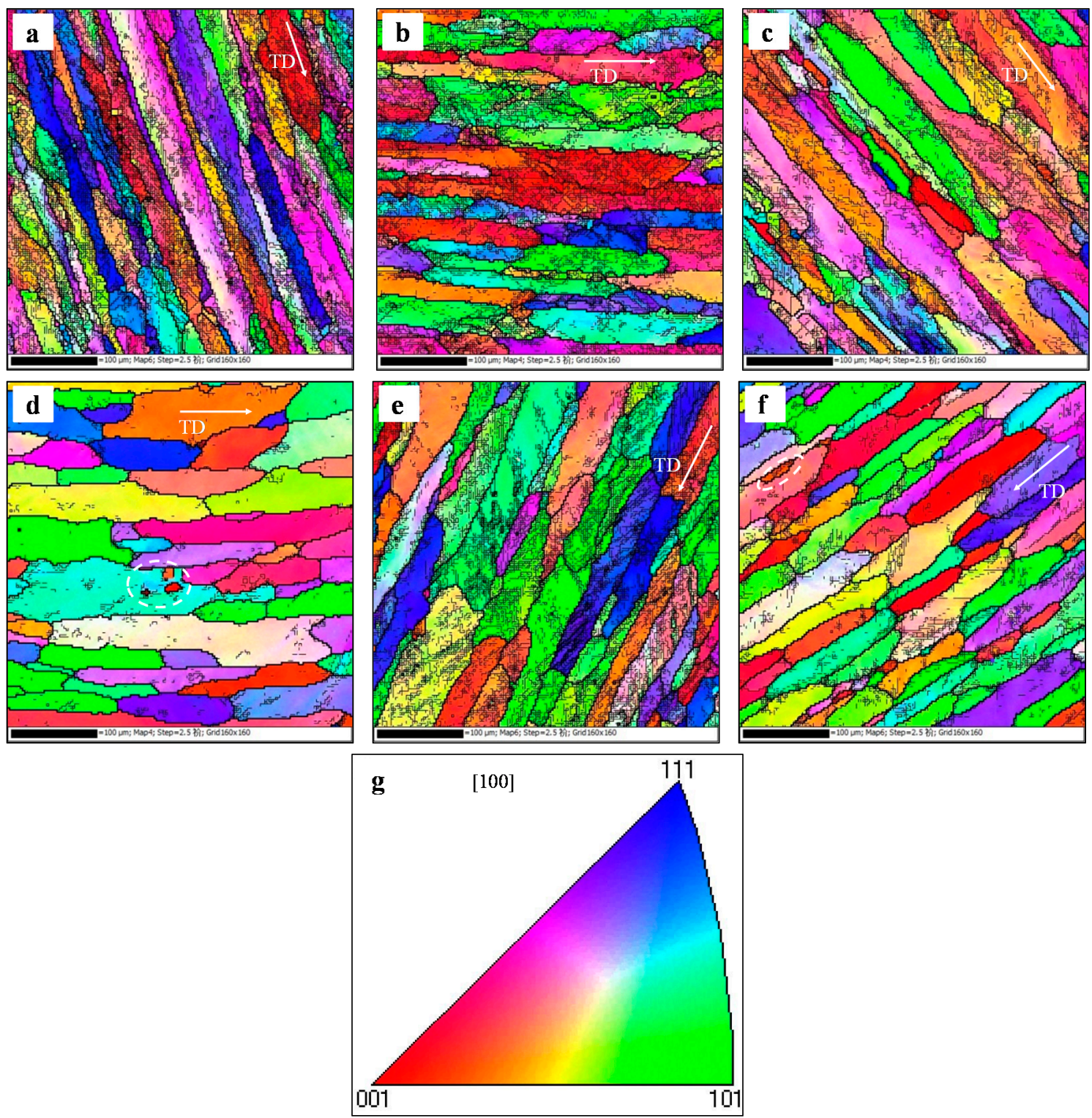

Figure 4. Inverse pole figure (IPF) maps of the stretched alloy at (a) $\mathrm{T}=100{ }^{\circ} \mathrm{C}, \dot{\varepsilon}=0.0003 \mathrm{~s}^{-1}$; (b) $\mathrm{T}=150{ }^{\circ} \mathrm{C}, \dot{\varepsilon}=0.0003 \mathrm{~s}^{-1}$; (c) $\mathrm{T}=200{ }^{\circ} \mathrm{C}, \dot{\varepsilon}=0.0003 \mathrm{~s}^{-1}$; (d) $\mathrm{T}=250{ }^{\circ} \mathrm{C}, \dot{\varepsilon}=0.0003 \mathrm{~s}^{-1} ;(\mathbf{e}) \mathrm{T}=200{ }^{\circ} \mathrm{C}$, $\dot{\varepsilon}=0.003 \mathrm{~s}^{-1}$; and (f) $T=200{ }^{\circ} \mathrm{C}, \dot{\varepsilon}=0.00003 \mathrm{~s}^{-1}$. (g) Standard triangle for color code (Note: low-angle grain boundaries (LAGBs) and high-angle grain boundaries (HAGBs) are displayed by gray and black lines, respectively).

The distribution of grain boundary misorientation angles in different deformation conditions was evaluated by Channel 5 software (2009), as presented in Figure 5. In Figure 5a-d, the variations of mean misorientation angle and volume fraction of HAGBs increase with raising temperature at $0.0003 \mathrm{~s}^{-1}$. The maximum mean misorientation angle is $8.40^{\circ}$ at $250^{\circ} \mathrm{C}$. The volume fractions of HAGBs are $4.17 \%$, $5.37 \%, 7.65 \%$, and $17.10 \%$, respectively, at 100, 150, 200, and $250{ }^{\circ} \mathrm{C}$. In Figure $5 \mathrm{e}, \mathrm{f}$, the variations of mean misorientation angle and volume fraction of HAGBs increase with raising strain rate at $200{ }^{\circ} \mathrm{C}$. While the strain rate is reduced from $0.003 \mathrm{~s}^{-1}$ to $0.00003 \mathrm{~s}^{-1}$, the mean misorientation angle increases from $5.08^{\circ}$ to $6.71^{\circ}$, and the volume fraction of HAGBs increases from $6.69 \%$ to $12.41 \%$. 

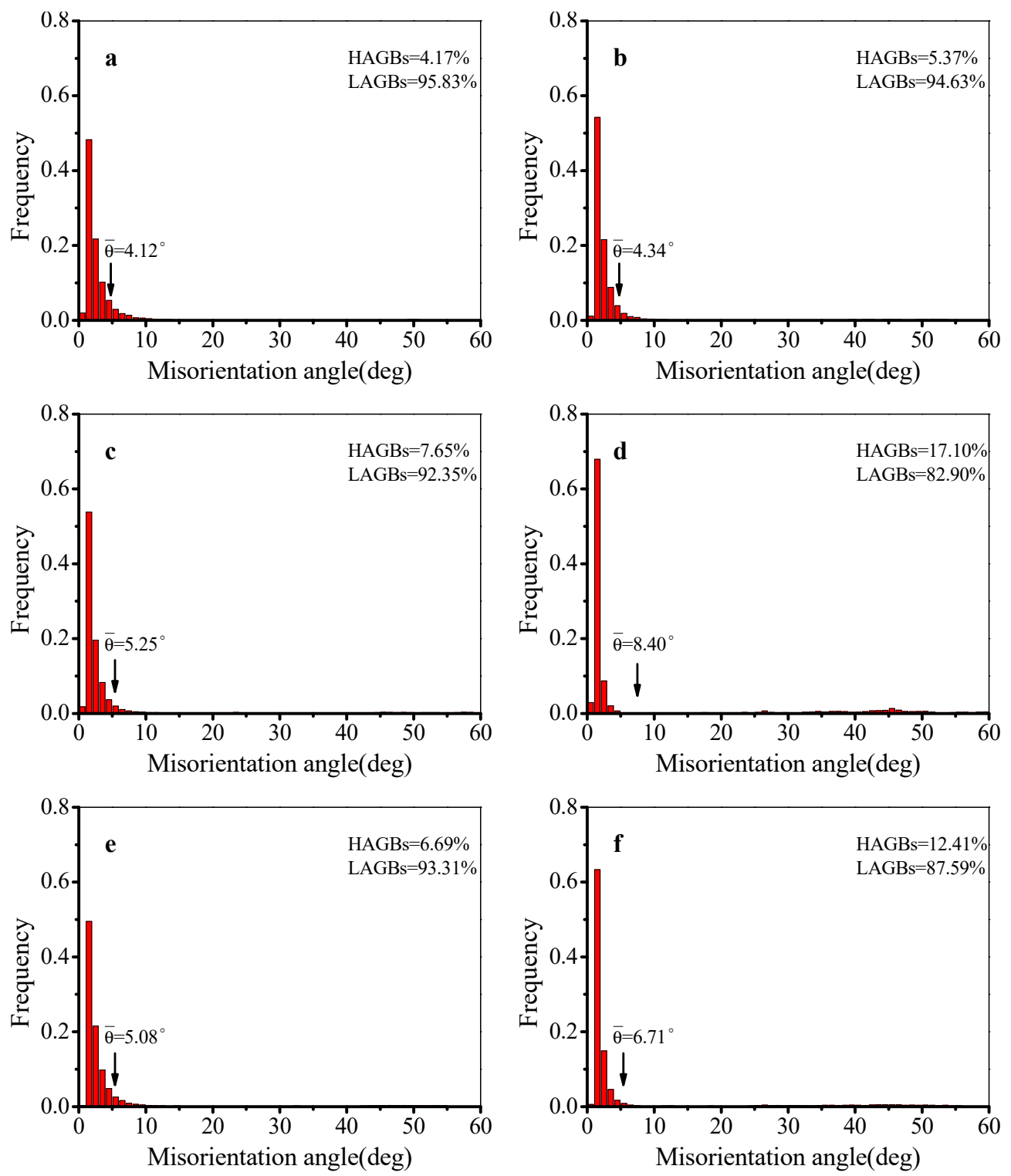

Figure 5. Distribution of grain boundary misorientation angles at (a) $\mathrm{T}=100{ }^{\circ} \mathrm{C}, \dot{\varepsilon}=0.0003 \mathrm{~s}^{-1}$; (b) $\mathrm{T}=150{ }^{\circ} \mathrm{C}, \dot{\varepsilon}=0.0003 \mathrm{~s}^{-1}$; (c) $\mathrm{T}=200{ }^{\circ} \mathrm{C}, \dot{\varepsilon}=0.0003 \mathrm{~s}^{-1}$; (d) $\mathrm{T}=250{ }^{\circ} \mathrm{C}, \dot{\varepsilon}=0.0003 \mathrm{~s}^{-1}$; (e) $\mathrm{T}=200{ }^{\circ} \mathrm{C}$, $\dot{\varepsilon}=0.003 \mathrm{~s}^{-1}$; and (f) $\mathrm{T}=200{ }^{\circ} \mathrm{C}, \dot{\varepsilon}=0.00003 \mathrm{~s}^{-1}$.

According to Figure 5, the proportion of HAGBs is low in the tested conditions. This is because the stacking fault energy of Al-Cu alloy is high. The main softening mechanism during hot deformation is DRV. While the temperature is over $200^{\circ} \mathrm{C}$, the proportion of HAGBs increases, which reveals the increased DRX degree. Based on previous research [42], when the deformation temperature is more than half of the melting temperature of $\mathrm{Al}-\mathrm{Cu}$ alloy, it is beneficial to the formation of DRX grains.

The kernel average misorientation (KAM) maps in the tested conditions are displayed in Figure 6. The values of $\mathrm{KAM}$ from $0^{\circ}$ to $5^{\circ}$ are marked as colors from blue to red. A large KAM value means a high geometrically necessary dislocation density $[43,44]$. In Figure $6 a-c$, it can be found that there are many green regions at different temperatures. Based on statistical analysis, the KAM values (mean local misorientation angle) are $2.00^{\circ}, 1.77^{\circ}$, and $1.59^{\circ}$, respectively, at 100,150 , and $200{ }^{\circ} \mathrm{C}$. When the temperature is raised to $250^{\circ} \mathrm{C}$, the dominant grains are blue color, and the value of KAM drops to $0.82^{\circ}$. The KAM maps of the stretched alloy at different strain rates are depicted in Figure $4 \mathrm{e}-\mathrm{f}$. As the strain rate decreases from $0.003 \mathrm{~s}^{-1}$ to $0.00003 \mathrm{~s}^{-1}$, the green regions decrease, and the value of KAM drops from $1.82^{\circ}$ to $1.20^{\circ}$. The value of KAM is low at high temperatures or low strain 
rates, which reveals that the geometrically necessary dislocation density is low. This is because the DRV becomes more and more obvious, which accelerates the dislocation annihilation. Furthermore, the decreased substructures reduce the flow stress.
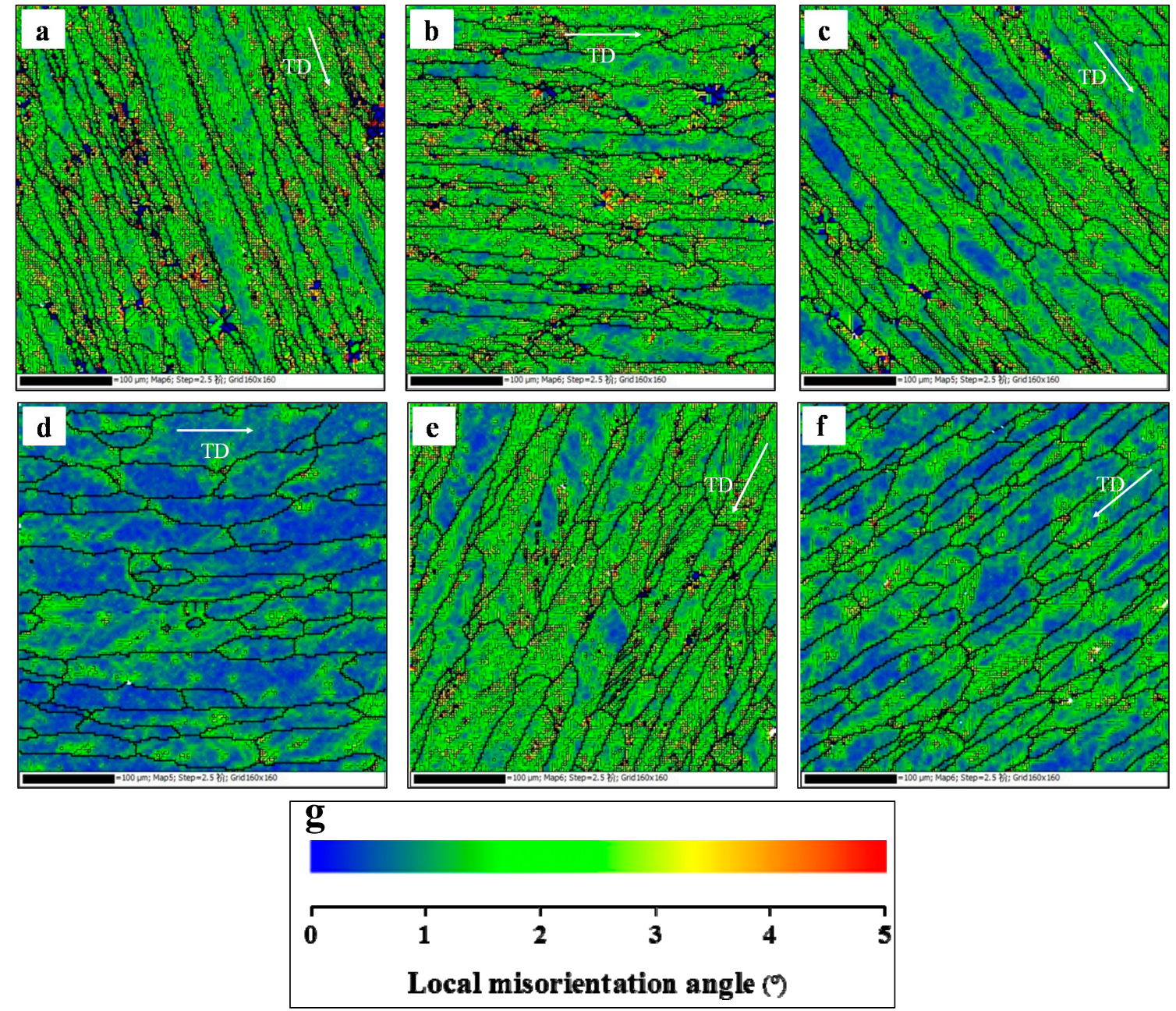

Figure 6. Kernel average misorientation (KAM) maps of the stretched alloy at (a) $\mathrm{T}=100{ }^{\circ} \mathrm{C}$, $\dot{\varepsilon}=0.0003 \mathrm{~s}^{-1} ;$ (b) $\mathrm{T}=150{ }^{\circ} \mathrm{C}, \dot{\varepsilon}=0.0003 \mathrm{~s}^{-1} ;$ (c) $\mathrm{T}=200{ }^{\circ} \mathrm{C}, \dot{\varepsilon}=0.0003 \mathrm{~s}^{-1} ;$ (d) $\mathrm{T}=250{ }^{\circ} \mathrm{C}, \dot{\varepsilon}=0.0003 \mathrm{~s}^{-1}$; (e) $\mathrm{T}=200{ }^{\circ} \mathrm{C}, \dot{\varepsilon}=0.003 \mathrm{~s}^{-1}$; and (f) $\mathrm{T}=200^{\circ} \mathrm{C}, \dot{\varepsilon}=0.00003 \mathrm{~s}^{-1}$; (g) The scale label.

\subsection{Precipitation Features}

Figure 7 shows the DSC curves of the solution-treated alloy. Theoretically, four endothermic peaks and four exothermic peaks can be found in the DSC curves. Furthermore, four endothermic peaks represent the dissolution of $\mathrm{Cu}$-rich clusters, G.P. zones, $\theta^{\prime \prime}$ and $\theta^{\prime}$ phases, while four exothermic peaks reveal the precipitation of G.P. zones, $\theta^{\prime \prime}, \theta^{\prime}$, and $\theta$ phases [45]. However, in actual experiments, not all the peaks can be fully found from the DSC curve due to the effect of heating rate. Rodríguez-Veiga et al. [46] found that few peaks can be observed when the heating rate is slow. In the present experimental curves, three peaks can be observed. Peak $\mathrm{A}_{1}$ resulted from the dissolution of G.P. zones, while peak $A_{2}$ was induced by the dissolution of $\theta^{\prime \prime}$ phases. Peak $B$ is related to the precipitation of $\theta^{\prime}$ phases. Because of the annihilation and overlap of peaks, the dissolution peaks of $\mathrm{Cu}$-rich clusters, as well as the precipitation peaks of G.P. zones and $\theta^{\prime \prime}$ phases, cannot be easily observed. The temperature ranges of the dissolution peak of $\mathrm{Cu}$-rich clusters, the precipitation peak of G.P. zones, and the precipitation peak of $\theta^{\prime \prime}$ phases are $50-85^{\circ} \mathrm{C}, 105-125{ }^{\circ} \mathrm{C}$, and $175-190{ }^{\circ} \mathrm{C}$, respectively. The four tested deformation temperatures $\left(100,150,200\right.$, and $\left.250^{\circ} \mathrm{C}\right)$ correspond to the 
four positions ( $a, b, c$, and d) marked in the curves. Cu-rich clusters and G.P. zones formed after the alloy were heated to $100{ }^{\circ} \mathrm{C}$ and $150^{\circ} \mathrm{C}$, respectively. $\theta^{\prime \prime}$ phases are presented in the matrix when the alloy was heated to $200^{\circ} \mathrm{C}$ and $250^{\circ} \mathrm{C}$. Thus, the influences of heating process before deformation on the type of precipitates are significant. This is further discussed following the TEM observation.

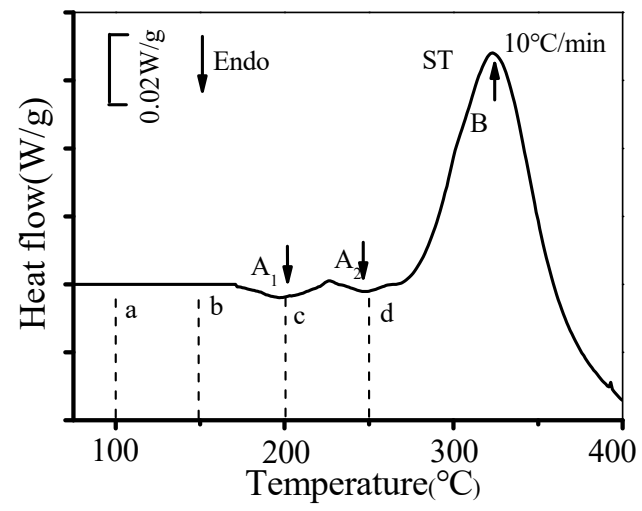

Figure 7. Differential scanning calorimetry (DSC) curves of the solution-treated alloy.

Figure 8 displays the TEM images and selected area electron diffraction (SAED) patterns of the heated alloy. Here, the heating rate is $10^{\circ} \mathrm{C} / \mathrm{min}$, while the target temperatures are $150{ }^{\circ} \mathrm{C}$ and $250{ }^{\circ} \mathrm{C}$. As depicted in Figure 8a, some dislocations can be found in the matrix at $150{ }^{\circ} \mathrm{C}$. The $\mathrm{Cu}$-rich clusters can be observed among dislocations. The SAED pattern reveals the continuous streaks along the $\{020\}_{\mathrm{Al}}$ position. These are some main characteristics of G.P. zones formed during heating [47,48]. When the target temperature is $250{ }^{\circ} \mathrm{C}$ (Figure $8 \mathrm{~b}$ ), dislocations can still be seen in matrix. In addition, some needle-like precipitates appear in the matrix. In the high-multiple TEM images (Figure 8c), the length of these phases is around $10 \mathrm{~nm}$, and the type of these phases is $\theta^{\prime \prime}$, which is further confirmed by the SAED pattern. Discontinuous streaks appear along $\{020\}_{\mathrm{Al}}$ position, revealing the precipitation of $\theta^{\prime \prime}$ phases $[49,50]$.
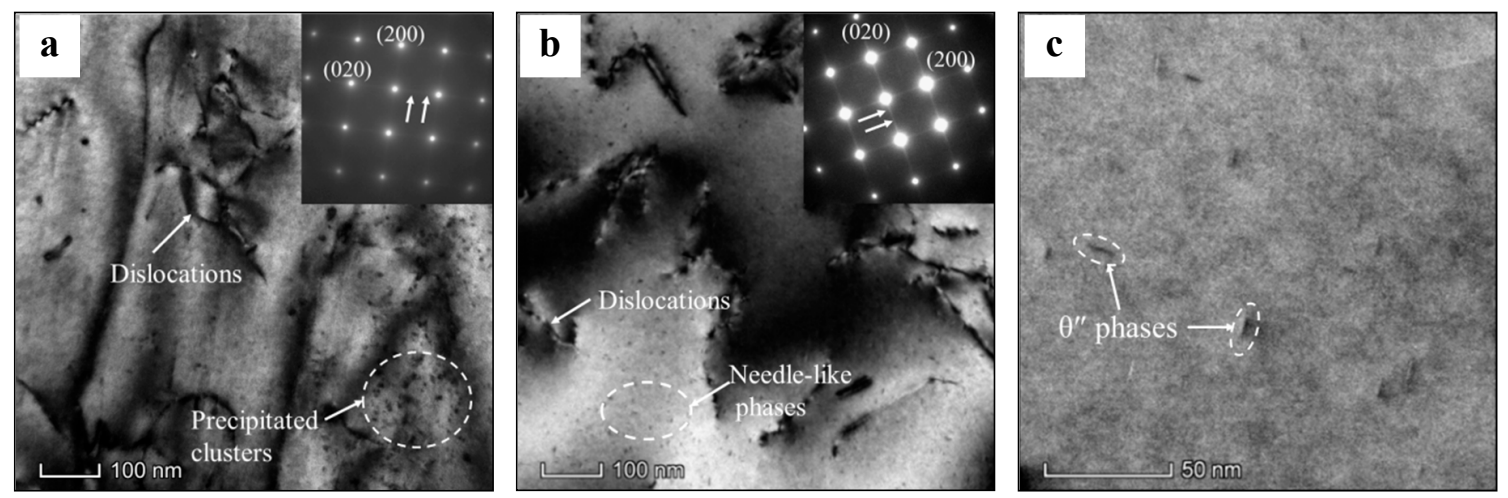

Figure 8. TEM images and selected area electron diffraction (SAED) patterns of the alloy heated to target temperatures of $(\mathbf{a}) 150^{\circ} \mathrm{C}$, and $(\mathbf{b}, \mathbf{c}) 250^{\circ} \mathrm{C}$.

Figure 9 displays the DSC curves and the relative volume fractions (RVFs) of $\theta^{\prime}$ phases in the stretched alloy. Two characteristic peaks (endothermic peak A and exothermic peak B) appear in most DSC curves. The endothermic peak becomes large because of the overlap of peaks $A_{1}$ and $A_{2}$, which indicates the dissolution of G.P. zones and $\theta^{\prime \prime}$ phases. Peak B is correlated with the additional precipitation of $\theta^{\prime}$ particles. The decreased strain rate increases the characteristic temperature of peak A. This is because the migration of vacancies is more sufficient, and more G.P. zones transform to $\theta^{\prime \prime}$ phases. Thus, the stability of precipitates is increased when the strain rate is decreased. Therefore, peak A moves toward a high-temperature region, while the characteristic temperature of peak $B$ 
moves toward a low-temperature region. This is because the nucleation of $\theta^{\prime}$ phases is affected by dislocations, and the deformation energy storage is low at low strain rates. The area of peak $\mathrm{B}$ decreases due to the decreased untransformed $\theta^{\prime \prime}$ phases. However, when the strain rate is $0.00003 \mathrm{~s}^{-1}$, it is hard to distinguish the endothermic peak and exothermic peak B from DSC curves at $200{ }^{\circ} \mathrm{C}$ and $250^{\circ} \mathrm{C}$ (Figure 9c,d). This indicates that almost all the $\theta^{\prime \prime}$ phases transform to $\theta^{\prime}$ phases in the deformation process.
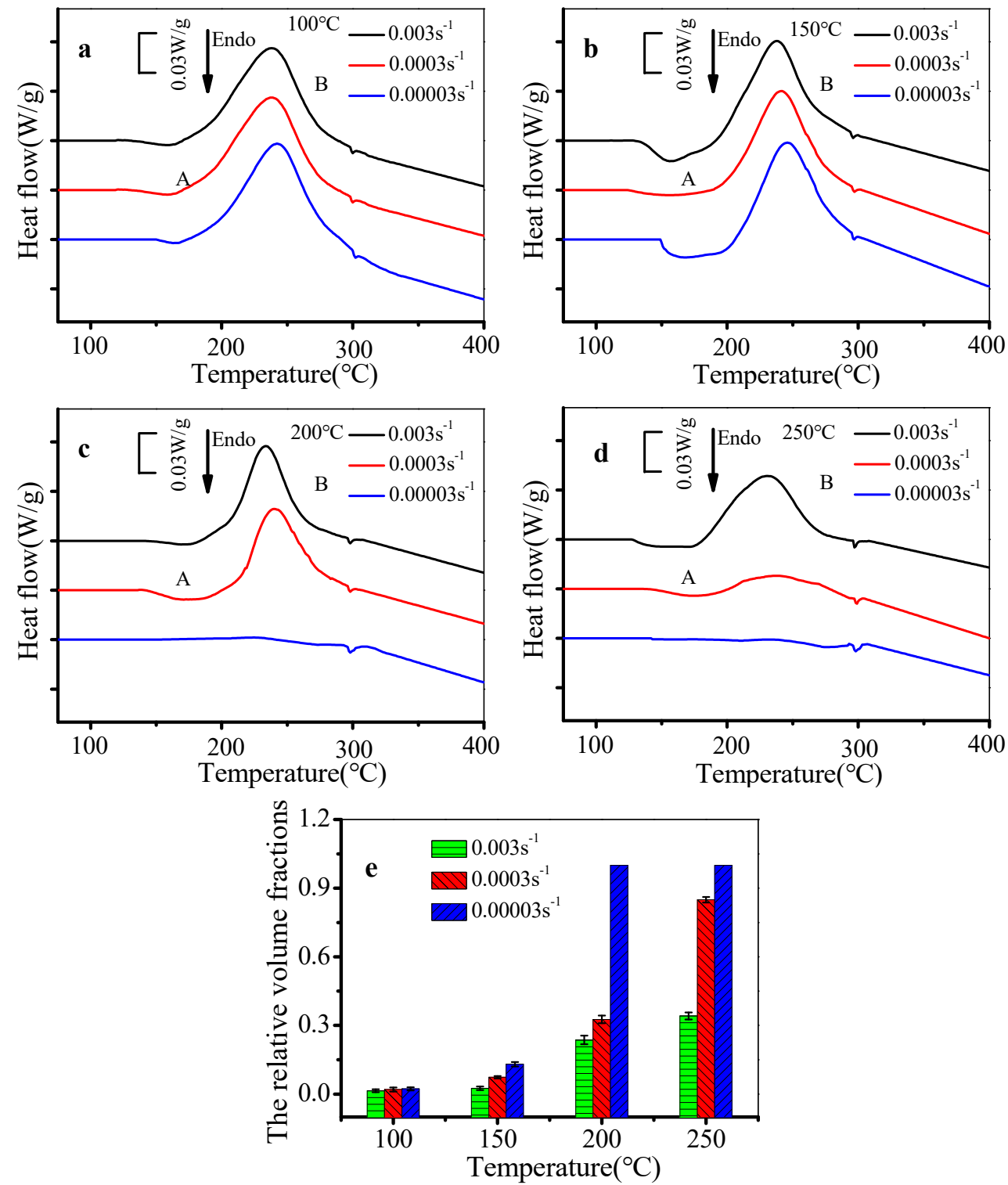

Figure 9. DSC curves and the relative volume fraction (RVF) of $\theta^{\prime}$ phases of the stretched alloy at (a) $100{ }^{\circ} \mathrm{C}$, (b) $150{ }^{\circ} \mathrm{C}$, (c) $200{ }^{\circ} \mathrm{C}$, and (d) $250{ }^{\circ} \mathrm{C}$. (e) The RVF of $\theta^{\prime}$ phases.

The area of peak B in the tested deformation conditions was calculated. The RVF of $\theta^{\prime}$ phases can be evaluated as follows [51]:

$$
f=\frac{A_{1}-A_{2}}{A_{1}},
$$

where $f$ is the RVF of $\theta^{\prime}$ phases, $\mathrm{A}_{2}$ is the area of peak $\mathrm{B}$ in the tested deformation conditions, and $A_{1}$ is the area of peak $\mathrm{B}$ in the solution-treated condition. The $\theta^{\prime}$ phases cannot be found in the solution-treated alloy, and the maximum content of $\theta^{\prime}$ phases could precipitate in the DSC experimental process. Thus, the area of peak B of the solution-treated alloy was taken as the denominator of 
Equation (1). The experimental results are shown in Figure 9e. At the same temperature, the RVF of $\theta^{\prime}$ phases of the stretched alloy increases with the decreased strain rate. The transformation of phases is more complete because of the longer deformation time at lower strain rates. At the same strain rate, the RVF of $\theta^{\prime}$ phases of the stretched alloy increases with the raised temperature. Firstly, the types of precipitates are affected by the heating process before deformation. $\theta^{\prime \prime}$ phases are present in matrix after heating to $200{ }^{\circ} \mathrm{C}$ and $250{ }^{\circ} \mathrm{C}$, and they quickly transform to $\theta^{\prime}$ phases in the tensile deformation process. Secondly, the activation energy is high at high temperatures, which promotes the transformation of precipitates.

Figure 10 illustrates the TEM images and SAED patterns of the stretched alloy in tested deformation conditions. When the strain rate is $0.0003 \mathrm{~s}^{-1}$, the type, content, and size of precipitates are affected by the deformation temperature, as shown in Figure 10a-d. In Figure 10a, rod-like undissolved particles are present in the matrix at $100^{\circ} \mathrm{C}$. It is hard to distinguish the precipitates from the TEM image and SAED pattern. In Figure 10b, some clusters can be seen at $150^{\circ} \mathrm{C}$. Meanwhile, continuous streaks along the $\{020\}_{\mathrm{Al}}$ position in the SAED pattern reveal the appearance of G.P. zones. In Figure 10c, some needle-like precipitates appear at $200{ }^{\circ} \mathrm{C}$, and their length range is between $10 \mathrm{~nm}$ and $18 \mathrm{~nm}$. Furthermore, these precipitates are confirmed as $\theta^{\prime \prime}$ phases by the discontinuous streaks in the SAED pattern, which prefer to precipitate along the $\{020\}_{\mathrm{Al}}$ direction due to the effects of tensile force. This is the so-called stress orientation effect $[44,52]$. The content and size of needle-like precipitates increase while the temperature is raised to $250^{\circ} \mathrm{C}$ (Figure 9d). The length of these precipitates varies from $41 \mathrm{~nm}$ to $92 \mathrm{~nm}$. According to the SAED pattern, diffraction spots at the $\{110\}_{\mathrm{Al}}$ site indicate the formation of $\theta^{\prime}$ phases $[44,46,53] . \theta^{\prime}$ phases also prefer to precipitate along the $\{020\}_{\mathrm{Al}}$ direction. Except for the deformation temperature, Figure 10c,e shows that the type, content, and size of precipitates are also influenced by strain rate. The content and size of the needle-like precipitates rise as the strain rate is reduced from $0.0003 \mathrm{~s}^{-1}$ to $0.00003 \mathrm{~s}^{-1}$. The diffraction spots show that the precipitates are mainly $\theta^{\prime}$ phases. In addition, the distribution of these precipitates is not uniform, but most $\theta^{\prime}$ phases precipitate along the $\{020\}_{\mathrm{Al}}$ direction.

Therefore, the type, content, and size of precipitates are affected by strain rate and deformation temperature. According to the above analysis, in the heating process before tensile deformation, the transformation of precipitates (G.P. zones $\rightarrow \theta^{\prime \prime}$ phases $\rightarrow \theta^{\prime}$ phases) is more sufficient at higher temperatures. During tensile deformation, the content and size of precipitates further increase due to the enhanced activation energy at lower strain rates or higher deformation temperatures. Meanwhile, the transformation rate of precipitates is accelerated, resulting in the increased $\theta^{\prime}$ and $\theta^{\prime \prime}$ phases. However, $\theta^{\prime}$ and $\theta^{\prime \prime}$ phases prefer to precipitate along the $\{020\}_{\mathrm{Al}}$ direction due to the stress orientation effect, which results in the uneven distribution of phases.

\subsection{Effects of Deformation Parameters on Mechanical Properties and Fracture Morphologies}

Figure 11 shows the mechanical properties of the stretched alloy at $100{ }^{\circ} \mathrm{C}$ and $150{ }^{\circ} \mathrm{C}$. The mechanical properties are usually affected by dislocation density, as well as the type, size, and content of precipitates. Based on the above analysis, the size and content of precipitates are relatively small at $100{ }^{\circ} \mathrm{C}$ and $150{ }^{\circ} \mathrm{C}$, which slightly influence the mechanical properties. Thus, the mechanical properties are mainly affected by dislocation density. With the increased temperature or the decreased strain rate, the dislocation multiplication and work hardening weaken, leading to the decreased yield strength (Figure 11a). From Figure 11b, the tensile strength drops with the decreased strain rate or the increased temperature. This is because the DRV is more obvious at lower strain rates or higher temperatures. Then, the dislocation density is decreased. In Figure 11c, the elongation increases with the raised temperature or the decreased strain rate, because the plastic deformation is more uniform due to the enhanced DRV. 

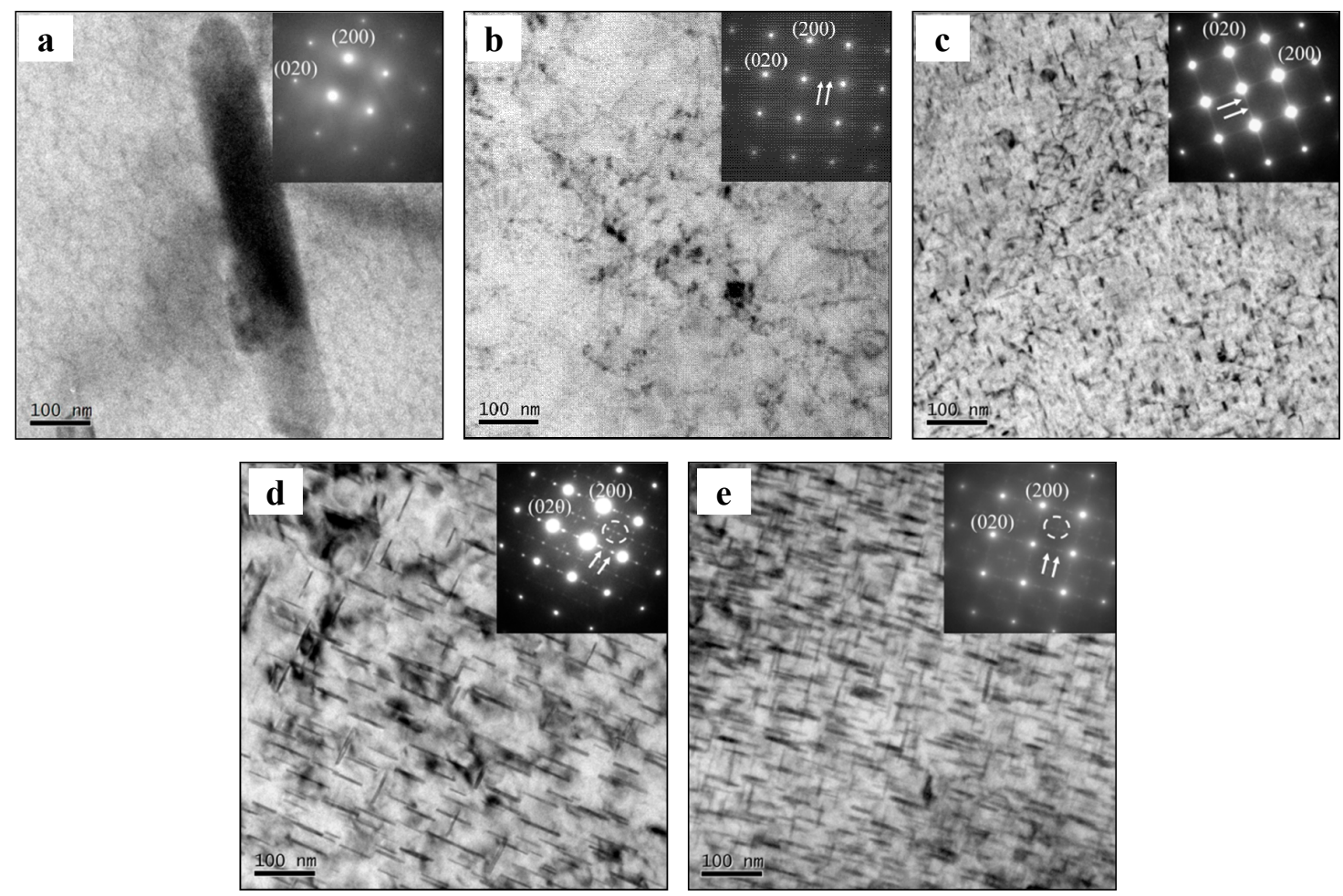

Figure 10. TEM images and SAED patterns of the stretched alloy at (a) $T=100{ }^{\circ} \mathrm{C}, \dot{\varepsilon}=0.0003 \mathrm{~s}^{-1}$; (b) $T=150{ }^{\circ} \mathrm{C}, \dot{\varepsilon}=0.0003 \mathrm{~s}^{-1}$; (c) $T=200{ }^{\circ} \mathrm{C}, \dot{\varepsilon}=0.0003 \mathrm{~s}^{-1}$; (d) $T=250{ }^{\circ} \mathrm{C}, \dot{\varepsilon}=0.0003 \mathrm{~s}^{-1}$; and (e) $T=200{ }^{\circ} \mathrm{C}, \dot{\varepsilon}=0.00003 \mathrm{~s}^{-1}$.
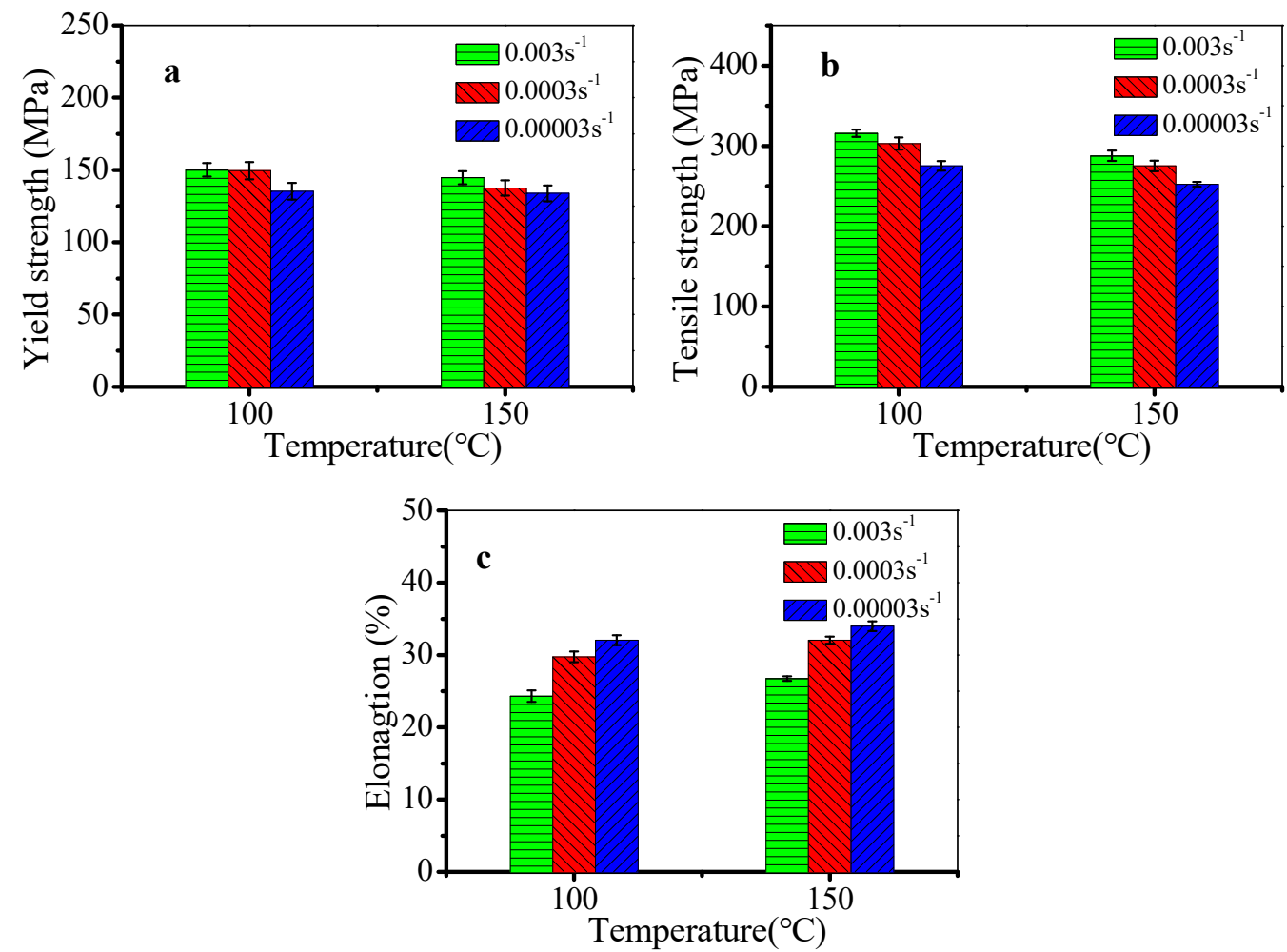

Figure 11. Mechanical properties of the stretched alloy at $100{ }^{\circ} \mathrm{C}$ and $150{ }^{\circ} \mathrm{C}$ : (a) yield strength; (b) tensile strength; (c) elongation. 
Figure 12 shows the mechanical properties of the stretched alloy at $200^{\circ} \mathrm{C}$ and $250{ }^{\circ} \mathrm{C}$. Based on the above analysis, $\theta^{\prime \prime}$ phases precipitate in the heating process before deformation. During deformation, the transformation of precipitates is more sufficient, increasing the content of $\theta^{\prime}$ phases. Thus, the mechanical properties are mainly affected by the dislocation and precipitates. With the decreased strain rate, the dislocation multiplication and work hardening weaken. However, the contents of $\theta^{\prime \prime}$ and $\theta^{\prime}$ phases increase, which enhances the pinning effect of precipitates on dislocations. By combining the effect of strengthening from dislocation and precipitation, the yield strength firstly decreases and then increases (Figure 12a). In spite of the content and size of precipitates increasing with the decreased strain rate, the interaction between dislocations and precipitates is weak due to the decreased dislocation density. Thus, the tensile strength drops with the decreased strain rate or the increased temperature, as shown in Figure 12b. In Figure 12c, the elongation decreases with the decreased strain rate or the increased temperature. This is because the deformation time is long when the strain rate is low. The content and size of $\theta^{\prime \prime}$ and $\theta^{\prime}$ phases increase, and the incompatible deformation between phases and matrix increases. Therefore, the plasticity of the alloy decreases.
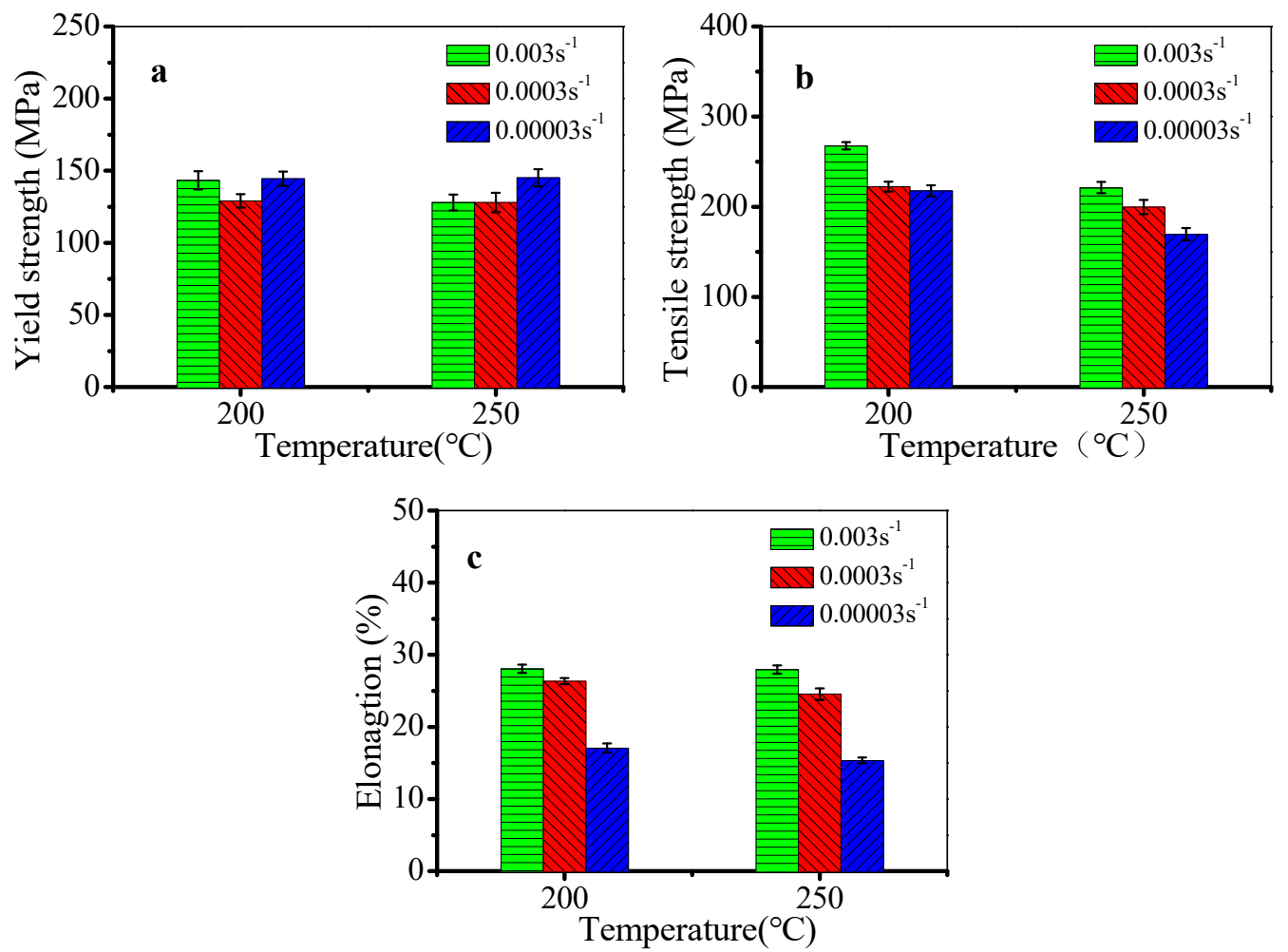

Figure 12. Mechanical properties of the stretched alloy at $200{ }^{\circ} \mathrm{C}$ and $250{ }^{\circ} \mathrm{C}$ : (a) yield strength; (b) tensile strength; (c) elongation.

Figure 13 shows the fracture morphologies of samples. In Figure 13a, there are a lot of equiaxial dimples on the fracture surface, implying the shear fracture mode. The serpentine sliding and sharp tearing edges can be observed on dimple walls, i.e., the fracture mechanism is micro-void coalescence [54]. In addition, the second phase can also be seen at the bottom of the dimples. From Figure $13 \mathrm{a}-\mathrm{c}$, at $200{ }^{\circ} \mathrm{C}$, the number and depth of dimples decrease with the decrease in stain rate. Meanwhile, the inhomogeneity of dimple sizes increases. This indicates that the plastic deformation is more uneven at a lower strain rate. Figure $13 \mathrm{~b}, \mathrm{~d}$ shows the fracture morphologies at different temperatures when the strain rate is $0.0003 \mathrm{~s}^{-1}$. As the temperature is increased from $200{ }^{\circ} \mathrm{C}$ to $250^{\circ} \mathrm{C}$, the number of dimples decreases, and the inhomogeneity of dimple sizes increases. It can be concluded that the plastic deformation is more uneven with the increased temperature. 

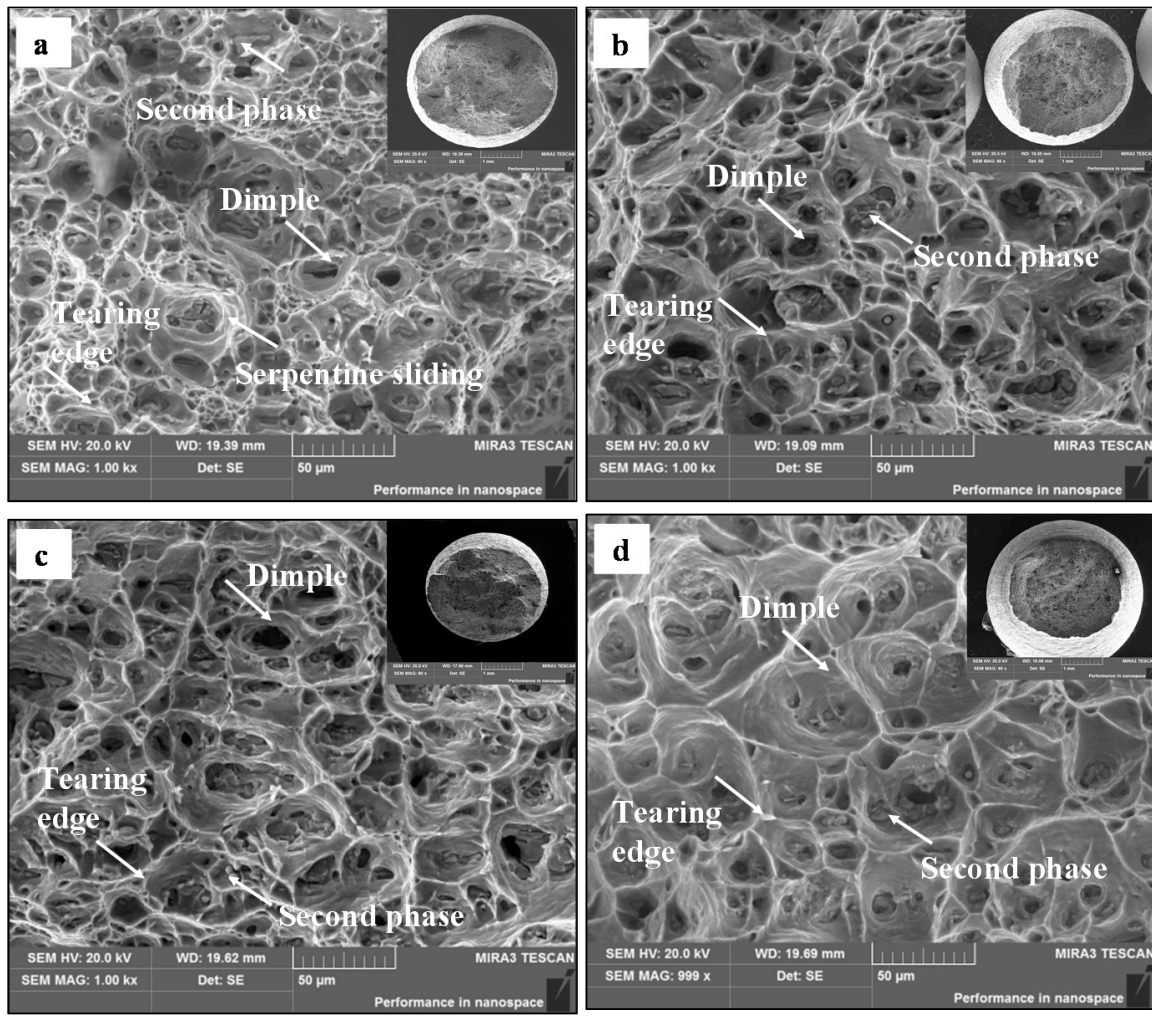

Figure 13. Fracture morphologies of the stretched alloy at (a) $\mathrm{T}=200{ }^{\circ} \mathrm{C}, \dot{\varepsilon}=0.003 \mathrm{~s}^{-1} ;$ (b) $\mathrm{T}=200{ }^{\circ} \mathrm{C}$, $\dot{\varepsilon}=0.0003 \mathrm{~s}^{-1}$; (c) $\mathrm{T}=200^{\circ} \mathrm{C}, \dot{\varepsilon}=0.00003 \mathrm{~s}^{-1}$; and (d) $\mathrm{T}=250{ }^{\circ} \mathrm{C}, \dot{\varepsilon}=0.0003 \mathrm{~s}^{-1}$.

\section{Conclusions}

The deformation behavior and precipitation features in a stretched 2219 aluminum alloy at intermediate temperatures were studied. Several important conclusions are given below.

- The flow stress monotonically rises at $100{ }^{\circ} \mathrm{C}$ and $150{ }^{\circ} \mathrm{C}$ due to the dominant work hardening. When the temperature is raised to $200^{\circ} \mathrm{C}$ and $250{ }^{\circ} \mathrm{C}$, the enhanced dynamic recovery reduces substructures. The dynamic recovery becomes more obvious at lower strain rates. Meanwhile, some dynamic recrystallization grains appear due to the rotation of small substructures. Thus, the true stress firstly increases and then keeps stable or drops with increasing true strain.

- The type of precipitates is greatly affected by the heating process before deformation. When the alloy is heated to $100^{\circ} \mathrm{C}$ and $150^{\circ} \mathrm{C}, \mathrm{Cu}$-rich clusters and G.P. zones appear. When the alloy is heated to $200^{\circ} \mathrm{C}$ and $250^{\circ} \mathrm{C}, \theta^{\prime \prime}$ phases precipitate.

- The content and size of precipitates increase due to the enhanced activation energy at lower strain rates or higher deformation temperatures. Meanwhile, the transformation of precipitates is accelerated, and $\theta^{\prime}$ and $\theta^{\prime \prime}$ phases increase. However, $\theta^{\prime}$ and $\theta^{\prime \prime}$ phases prefer to precipitate along the $\{020\}_{\mathrm{Al}}$ direction due to the stress orientation effect, which results in the uneven distribution of phases.

- To alleviate work hardening and avoid the inhomogeneous precipitation of phases, the reasonable strain rate and temperature are about $0.0003 \mathrm{~s}^{-1}$ and $150{ }^{\circ} \mathrm{C}$, respectively.

Author Contributions: Y.C.L.: the main and corresponding author, performed most of the experiments, and evaluated the results. W.-Y.D.: Data curation, Investigation, Writing-original draft. X.-H.Z.: Data curation, Investigation. Q.W.: Investigation, Writing—review \& editing. Y.-J.H.: Data curation, Investigation. All authors have read and agreed to the published version of the manuscript.

Funding: This work was supported by the National Natural Science Foundation Council of China (Grant No. 51775564).

Conflicts of Interest: The authors declare no conflicts of interest. 


\section{References}

1. Lin, Y.C.; Xia, Y.C.; Jiang, Y.Q.; Zhou, H.M.; Li, L.T. Precipitation hardening of 2024-T3 aluminum alloy during creep aging. Mater. Sci. Eng. A 2013, 565, 420-429. [CrossRef]

2. Rasaee, S.; Mirzaei, A.H. Constitutive modeling of 2024 aluminum alloy based on the Johnson-Cook model. Trans. Indian Inst. Met. 2019, 72, 1023-1030. [CrossRef]

3. Choi, H.; Lee, D.; Ahn, S.; Lee, C.; Kim, S. Stress corrosion cracking sensitivity of high-strength 2xxx series aluminum alloys in 3.5\% NaCl solution. Korean J. Mater. Res. 2018, 28, 738-747. [CrossRef]

4. Li, B.; Pan, Q.L.; Yin, Z.M. Characterization of hot deformation behavior of as-homogenized Al-Cu-li-Sc-Zr alloy using processing maps. Mater. Sci. Eng. A 2018, 614, 199-206. [CrossRef]

5. Trimble, D.; O'Donnell, G.E. Flow stress prediction for hot deformation processing of 2024Al-T3 alloy. Trans. Nonferrous Met. Soc. China 2016, 26, 1232-1250. [CrossRef]

6. Lin, Y.C.; Wu, Q.; He, D.G.; Zhu, X.H.; Liu, D.Y.; Li, X.H. Effects of solution time and cooling rate on microstructures and mechanical properties of $2219 \mathrm{Al}$ alloy for a larger spun thin-wall ellipsoidal head. J. Mater. Res. Technol. 2020. [CrossRef]

7. Liu, L.; Wu, Y.X.; Gong, H.; Li, S.; Ahmad, A.S. A physically based constitutive model and continuous dynamic recrystallization behavior analysis of 2219 aluminum alloy during hot deformation process. Materials 2018, 11, 1443. [CrossRef]

8. Teymoory, P.; Zarei-Hanzaki, A.; Shafieizad, A.H.; Abedi, H.R.; Vesely, J.; Ebrahimi, M. Evaluating the high temperature superplastic behavior of a thermomechanically processed $\mathrm{Al}-\mathrm{Cu}$ aluminum alloy through miniaturized testing method. Mater. Res. Express 2019, 6, 105010. [CrossRef]

9. Wang, Y.X.; Zhao, G.Q.; Xu, X.; Chen, X.X.; Zhang, C.S. Constitutive modeling, processing map establishment and microstructure analysis of spray deposited Al-Cu-Li alloy 2195. J. Alloy. Compd. 2019, 779, 735-751. [CrossRef]

10. Wang, W.G.; Wang, G.; Guo, G.N.; Rong, Y.M. Competitive relationship between thermal effect and grain boundary precipitates on the ductility of an as-quenched Al-Cu-Mn alloy. Int. J. Damage Mech. 2018, 27, 779-798. [CrossRef]

11. Zhang, J.; Chen, B.; Zhang, B.X. Effect of initial microstructure on the hot compression deformation behavior of a 2219 aluminum alloy. Mater. Des. 2012, 34, 15-21. [CrossRef]

12. Wu, J.J.; Guo, R.C. Constitutive behavior for quenching of $\mathrm{Al}-\mathrm{Cu}-\mathrm{Mg}$ alloy with consideration of precipitation. J. Eng. Mater. Technol. 2018, 140, 041009. [CrossRef]

13. Bai, Z.H.; Qiu, F.; Liu, Y.Y.; Zhou, W.; Jiang, Q.C. Age hardening and mechanical properties of cast Al-Cu alloy modified by La and Pr. Adv. Eng. Mater. 2015, 17, 143-147. [CrossRef]

14. Mokdad, F.; Chen, D.L.; Liu, Z.Y.; Ni, D.R.; Xiao, B.L.; Ma, Z.Y. Three-dimensional processing maps and microstructural evolution of a CNT-reinforced Al-Cu-Mg nanocomposite. Mater. Sci. Eng. A 2017, 702, 425-437. [CrossRef]

15. Bo, G.W.; Jiang, F.L.; Dong, Z.Y.; Wang, G.; Zhang, H. Revealing the influence of preprecipitation microstructure on hot workability in an Al-Cu-Mg-Zr alloy. Mater. Sci. Eng. A 2019, 755, 147-157. [CrossRef]

16. Liu, L.; Wu, Y.X.; Gong, H.; Dong, F.; Ahmad, A.S. Modified kinetic model for describing continuous dynamic recrystallization behavior of $\mathrm{Al} 2219$ alloy during hot deformation process. J. Alloy. Compd. 2020, 817, 153301. [CrossRef]

17. Chen, G.; Lu, L.P.; Ren, C.Z.; Ge, X. Temperature dependent negative to positive strain rate sensitivity and compression behavior for 2024-T351 aluminum alloy. J. Alloys Compd. 2018, 765, 569-585. [CrossRef]

18. Liu, L.; Wu, Y.X.; Gong, H.; Wang, K. Modification of constitutive model and evolution of activation energy on 2219 aluminum alloy during warm deformation process. Trans. Nonferrous Met. Soc. China 2019, 29, 448-459. [CrossRef]

19. Wei, D.B.; Yang, K.; Zhang, P.Z.; Li, F.K.; Liang, H.X.; Yao, Z.J. Morphological evolution of S-phase in 2024 aluminum under tensile creep at 448-463 K. J. Mater. Eng. Perform. 2019, 28, 3614-3621. [CrossRef]

20. García-Hernández, J.L.; Garay-Reyes, C.G.; Gómez-Barraza, I.K.; Ruiz-Esparza-Rodríguez, M.A.; Gutiérrez-Castañeda, E.J.; Estrada-Guel, I.; Maldonado-Orozco, M.C.; Martínez-Sánchez, R. Influence of plastic deformation and $\mathrm{Cu} / \mathrm{Mg}$ ratio on the strengthening mechanisms and precipitation behavior of AA2024 aluminum alloys. J. Mater. Res. Technol. 2019, 8, 5471-5475. [CrossRef] 
21. Song, Y.F.; Ding, X.F.; Zhao, X.J.; Xiao, L.R.; Guo, L. The effect of stress-aging on dimensional stability behavior of Al-Cu-Mg alloy. J. Alloy. Compd. 2017, 718, 298-303. [CrossRef]

22. Paoletti, C.; Regev, M.; Spigarelli, S. Modelling of creep in alloys strengthened by rod-shaped particles: $\mathrm{Al}-\mathrm{Cu}-\mathrm{Mg}$ age-hardenable alloys. Metals 2018, 8, 930. [CrossRef]

23. Li, Y.; Shi, Z.; Lin, J.G.; Yang, Y.L.; Rong, Q. Extended application of a unified creep-ageing constitutive model to multistep heat treatment of aluminium alloys. Mater. Des. 2017, 122, 422-432. [CrossRef]

24. Li, J.Y.; Chen, S.Y.; Li, F.S.; Chen, K.H.; Huang, L.P. Synergy effect of Si addition and pre-straining on microstructure and properties of $\mathrm{Al}-\mathrm{Cu}-\mathrm{Mg}$ alloys with a medium $\mathrm{Cu} / \mathrm{Mg}$ ratio. Mater. Sci. Eng. A 2019, 767, 138429. [CrossRef]

25. Mirzadeh, H. Simple physically-based constitutive equations for hot deformation of 2024 and 7075 aluminum alloys. Trans. Nonferrous Met. Soc. China 2015, 25, 1614-1618. [CrossRef]

26. El-Aty, A.A.; Xu, Y.; Zhang, S.H.; Ha, S.; Yan, M.; Chen, D.Y. Impact of high strain rate deformation on the mechanical behavior, fracture mechanisms and anisotropic response of $2060 \mathrm{Al}-\mathrm{Cu}-\mathrm{Li}$ alloy. J. Adv. Res. 2019, 18, 19-37. [CrossRef]

27. Lin, Y.C.; Chen, X.M.; Chen, M.S.; Zhou, Y.; Wen, D.X.; He, D.G. A new method to predict the metadynamic recrystallization behavior in a typical nickel-based superalloy. Appl. Phys. A 2016, 122, 601. [CrossRef]

28. Chen, D.D.; Lin, Y.C.; Chen, X.M. A strategy to control microstructures of a Ni-based superalloy during hot forging based on particle swarm optimization algorithm. Adv. Manufact. 2019, 7, 238-247. [CrossRef]

29. Lin, Y.C.; Wen, D.X.; Chen, M.S.; Chen, X.M. A novel unified dislocation density based model for hot deformation behavior of a nickel-based superalloy under dynamic recrystallization conditions. Appl. Phys. A 2016, 122, 805. [CrossRef]

30. Rezayat, M.; Parsa, M.H.; Mirzadeh, H.; Cabrera, J.M. Dynamic deformation response of Al-Mg and Al-Mg/B4C composite at elevated temperatures. Mater. Sci. Eng. A 2018, 712, 645-654. [CrossRef]

31. Lin, Y.C.; Zhao, C.Y.; Chen, M.S.; Chen, D.D. A novel constitutive model for hot deformation behaviors of Ti-6Al-4V alloy based on probabilistic method. Appl. Phys. A 2016, 122, 716. [CrossRef]

32. Lin, Y.C.; Luo, S.C.; Jiang, X.Y.; Tang, Y.; Chen, M.S. Hot deformation behavior of a Sr-modified Al-Si-Mg alloy: Constitutive model and processing maps. Trans. Nonferrous Met. Soc. China 2018, 28, 592-603. [CrossRef]

33. Lin, Y.C.; Liang, Y.J.; Chen, M.S.; Chen, X.M. A comparative study on phenomenon and deep belief network models for hot deformation behavior of an Al-Zn-Mg-Cu alloy. Appl. Phys. A 2017, 123, 68. [CrossRef]

34. Lin, Y.C.; He, M.; Chen, M.S.; Wen, D.X.; Chen, J. New insights into the effects of initial $\delta$ phase $(\mathrm{Ni3Nb}) \mathrm{on}$ hot tensile deformation behaviors and material constants of a Ni-based superalloy. Trans. Nonferrous Met. Soc. China 2016, 26, 107-117. [CrossRef]

35. Quan, G.Z.; Zou, Z.Y.; Wen, H.R.; Pu, S.A.; Lv, W.Q. A Characterization of Hot Flow Behaviors Involving Different Softening Mechanisms by ANN for As-Forged Ti-10V-2Fe-3Al Alloy. High Temp. Mater. Proc. 2015, 34, 651-665.

36. Lin, Y.C.; Xiaom, Y.W.; Jiang, Y.Q.; Pang, G.D.; Li, H.B.; Zhang, X.Y.; Zhou, K.C. Spheroidization and dynamic recrystallization mechanisms of Ti-55511 alloy with bimodal microstructures during hot compression in $\alpha+$ $\beta$ region. Mater. Sci. Eng. A 2020, 782, 139282. [CrossRef]

37. Lin, Y.C.; Pang, G.D.; Jiang, Y.Q.; Liu, X.G.; Zhang, X.Y.; Chen, C.; Zhou, K.C. Hot compressive deformation behavior and microstructural evolution of a Ti-55511 alloy with basket-weave microstructures. Vacuum 2019, 169, 108878. [CrossRef]

38. Quan, G.Z.; Shi, R.J.; Zhao, J.; Liu, Q.; Xiong, W.; Qiu, H.M. Modeling of dynamic recrystallization volume fraction evolution for AlCu4SiMg alloy and its application in FEM. Trans. Nonferrous Met. Soc. China 2019, 29, 1138-1151. [CrossRef]

39. Lin, Y.C.; Wu, X.Y.; Chen, X.M.; Chen, J.; Wen, D.X.; Zhang, J.L.; Li, L.T. EBSD study of a hot deformed nickel-based superalloy. J. Alloys Compd. 2015, 640, 101-113. [CrossRef]

40. Wang, S.; Luo, J.R.; Hou, L.G.; Zhuang, J.S. Physically based constitutive analysis and microstructural evolution of AA7050 aluminum alloy during hot compression. Mater. Des. 2016, 107, 277-289. [CrossRef]

41. Tomczyk, A.; Seweryn, A.; Gradzka-Dahlke, M. The effect of dynamic recrystallization on monotonic and cyclic behaviour of Al-Cu-Mg Alloy. Materials 2018, 11, 874. [CrossRef] [PubMed]

42. Sakai, T.; Belyakov, A.; Kaibyshev, R.; Miura, H.; Jonas, J.J. Dynamic and post-dynamic recrystallization under hot, cold and severe plastic deformation conditions. Prog. Mater Sci. 2014, 60, 130-207. [CrossRef] 
43. Chen, F.; Wang, H.; Zhu, H.; Cui, Z. Study on Dynamic Recrystallization Behaviors in a Hot-Deformed FB2 Ultra-supercritical Rotor Steel. Metall. Mater. Microstruct. Anal. 2019, 8, 145-158. [CrossRef]

44. Birosca, S.; Liu, G.; Ding, R.; Jiang, J.; Simm, T.; Deen, C.; Whittaker, M. The dislocation behaviour and GND development in a nickel based superalloy during creep. Int. J. Plast. 2019, 118, 252-268. [CrossRef]

45. Son, S.K.; Takeda, M.; Mitome, M.; Bando, Y.; Endo, T. Precipitation behavior of an Al-Cu alloy during isothermal aging at low temperatures. Mater. Lett. 2005, 59, 629-632. [CrossRef]

46. Rodríguez-Veiga, A.; Bellón, B.; Papadimitriou, I.; Esteban-Manzanares, G.; Sabirov, I.; LLorca, J. A multidisciplinary approach to study precipitation kinetics and hardening in an $\mathrm{Al}-4 \mathrm{Cu}(\mathrm{wt}$. \%) alloy. J. Alloy. Compd. 2018, 757, 504-519. [CrossRef]

47. Lin, Y.C.; Xia, Y.C.; Jiang, Y.Q.; Li, L.T. Precipitation in Al-Cu-Mg alloy during creep exposure. Mater. Sci. Eng. A 2012, 556, 796-800. [CrossRef]

48. Fonda, R.W.; Bingert, J.F. Precipitation and grain refinement in a $2195 \mathrm{Al}$ friction stir weld. Metall. Mater. Trans. A 2006, 37, 3593-3604. [CrossRef]

49. Liu, G.; Lin, Y.C.; Zhang, X.C.; Zhou, H.M.; Jiang, Y.Q. Effects of two-stage creep-aging on precipitates of an Al-Cu-Mg alloy. Mater. Sci. Eng. A 2014, 614, 45-53. [CrossRef]

50. Papazian, J.M. A calorimetric study of precipitation in aluminum alloy 2219. Metall. Mater. Trans. A 1981, 12, 269-280. [CrossRef]

51. Starink, M.J. Analysis of aluminium based alloys by calorimetry: Quantitative analysis of reactions and reaction kinetics. Int. Mater. Rev. 2004, 49, 191-226. [CrossRef]

52. Xu, F.S.; Zhang, J.; Deng, Y.L.; Zhang, X.M. Precipitation orientation effect of 2124 aluminum alloy in creep aging. Trans. Nonferrous Met. Soc. China 2014, 24, 2067-2071. [CrossRef]

53. Biswas, A.; Siegel, D.J.; Wolverton, C.; Seidman, D.N. Precipitates in Al-Cu alloys revisited: Atom-probe tomographic experiments and first-principles calculations of compositional evolution and interfacial segregation. Acta Mater. 2011, 59, 6187-6204. [CrossRef]

54. Lin, Y.C.; Zhu, X.H.; Dong, W.Y.; Yang, H.; Xiao, Y.W.; Kotkunde, N. Effects of deformation parameters and stress triaxiality on the fracture behaviors and microstructural evolution of an Al- $\mathrm{Zn}-\mathrm{Mg}-\mathrm{Cu}$ alloy. J. Alloy. Compd. 2020, 832, 154988. [CrossRef]

(C) 2020 by the authors. Licensee MDPI, Basel, Switzerland. This article is an open access article distributed under the terms and conditions of the Creative Commons Attribution (CC BY) license (http://creativecommons.org/licenses/by/4.0/). 